\title{
スーパーマーケットのエネルギー消費に関する研究(その1）： 店舗空調と冷蔵冷凍ショーケースの相互影響評価のための冷却負荷分析 STUDY ON ENERGY CONSUMPTION OF A GROCERY STORE (PART 1): REFRIGERATION LOAD ANALYSIS TO EVALUATE THE INTERACTION BETWEEN STORE SPACE CONDITIONING AND REFRIGERATED DISPLAY CASE
}

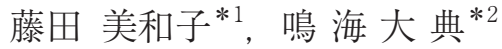 \\ Miwako FUJITA and Daisuke NARUMI
}

\begin{abstract}
In grocery stores, space conditioning and refrigerated display cases interact, making it difficult to study energy conservation through architectural ideas. The purpose of this study is to determine the indoor enthalpy based on the leakage heat of the display case and the space conditioning load, and to devise a method for calculating store energy by combining the space conditioning load calculation and the refrigeration load calculation.

In this report (1st report), five types of refrigerated display cases were tested and the enthalpy characteristic equation for total heat and latent heat was obtained.
\end{abstract}

Keywords : Grocery Store, Refrigerated Display Case, Experiments, Electric Power Consumption, Indoor environment, frozen and refrigerated スーパーマーケット, ショーケース，実験，消費電力，室内環境，冷蔵冷凍

1. はじめに

日本の最終エネルギー消費量変化をみると、1973 年から 2013 年の 増加割合では全体が 1.2 倍増に対し、業務部門では 2.4 倍と増加が顕 著である ${ }^{1)}$ 。製造業と比べて業務部門は事業コストに占めるエネルギ ーコストの割合が低く、自発的な省エネ化が進みにくい現状にあるが、 業務用の代表的なエネルギー消費機器である空調や照明については、 市場が大きいことから比較的低コストに省エネルギー機器が消費者 に提供される。一方、空調等と比較して市場規模が小さい冷設什器は 省エネルギー機器のコストが高くなり、コスト競争にさらされている 食品小売店舗では採用が難しいことが多い。その結果、冷設什器は省 エネルギー機器開発が進みにくい。食品小売店舗の省エネ化には、こ のような課題があることから、経済産業省は 2017 年に省エネ法を改 正し、冷蔵冷凍ショーケース（以下 $\mathrm{SC}$ ) の一部に対してトップラン ナー方式を取り入れ、機器の省エネ化を促進している。

建築的な観点からは、店舗のエネルギー消費を削減するには空調負 荷や泠却負荷（冷蔵冷凍負荷）の低減が必要であり、一般的には建物 の断熱強化や換気量・外気導入の抑制が考えられる。しかし、SC は 商品の取りやすさから室内空間に対して開放されていることが多い ため、空調負荷と冷却負荷には相互影響があり、単純な空調熱負荷計
算では店舗全体のエネルギー消費（空調と冷蔵冷凍）を予測すること ができない。SC の消費エネルギーは設備レイアウトや建築的な構造、 換気空調運用等により大きな影響を受けることから、店舗全体の省工 ネルギー検討をより複雑なものとしている。高い省エネルギー性能を 備えた SC を採用しつつ、その特性を理解し、様々な建築面、運用面 の配慮を行うことが店舗の省エネルギー化には必須である。

$\mathrm{SC}$ 冷却負荷特性や空調負荷との関係については、様々な研究結果 が報告されている。実在店舗の実測に関する研究では、白石ら ${ }^{2) か ゙ ~ S C ~}$ 周辺の温度環境が冷気漏れと空調負荷へ大きな影響を与えること、田 中ら ${ }^{3)}$ はデシカント空調の店内環境改善や除湿によるデフロストヒ 一タの消費電力変化について報告している。湯淺ら ${ }^{4}$ が SC と空調負 荷に着目し、それら電力消費量と外気温度に強い相関があることを示 している。エネルギー消費モデルとして、湯浅ら ${ }^{4}$ は SC の冷気漏れ 量を配慮して、SMASH を用いた負荷計算を試みているが、冷気漏れ については、エアカーテンの風量に一定の係数をかけた值を用いてい る。鳴海ら ${ }^{5)}$ は店舗の実測データから予測式を作成し、SC 種類の変 更や、店内環境温度を変更した場合の空調負荷を含めた省エネルギー 効果を計算している。

実験室における SC の詳細実験計測結果から、SC 冷却負荷特性や
*1 横浜国立大学大学院環境情報学府 大学院生·学士(工学) $/$ 中部電力エネルギー応用研究所 研究主査

$* 2$ 横浜国立大学大学院環境情報研究院 教授・博士 (工学
Grad. Student, Graduate School of Environment and Information Sciences, Yokohama National University, B.Eng. / Research Chief, Energy Applications Research and Development Center, Chubu Electric Power Co.

Prof., Graduate School of Environment and Information Sciences, Yokohama National University, Dr.Eng. 
消費電力特性を予測した報告もされている。Walker ら ${ }^{6}$ は開放型多段 SC の消費電力の詳細や冷却負荷特性を実験により明らかにし、ガラ スドアの設置やエアカーテンの改善、ファンやモータの改善による省 エネルギー寄与度を定量化した。V arela ら フはコンビニエンスストア をモデルとした SC について、実験データから各 SC の冷却負荷計算 式を作成した。それらに店内温湿度や外気温湿度を与えることで、消 費エネルギー計算を行い、日本の気候の違いによるエネルギー消費変 化を明らかにした。

食品小売店舗の消費エネルギー予測手法を確立するための課題を 以下に整理する。実在店舗の実測データを活用する場合は計測しやす い消費電力について分析評価される。実証データの回帰モデルを用い る場合は、当該店舗における省エネルギー運用の検討には有効である。 しかし、消費電力の分析では、その店舗の冷凍機と SC との組み合わ せによるシステム特性や、店舗の建物特性等が排除できないため、計 算手法を汎化することが難しい。鳴海 ${ }^{5}$ は汎化を目指し SC 冷却負荷 について店舗実測による計算を試みたが、営業店舗であるため計測精 度の問題がある。以上の課題があるため、消費エネルギー予測にとっ て重要なデータである SC 冷却負荷特性を実験室で取得する研究が行 われている。実験により多種の SC の冷却負荷を取得し分析すれば、 様々な SC を組み合わせた冷却負荷を計算することができる。既往文 献 6) 7)では多段 SC やコンビニエンスストアに設置されている SC に ついて分析しているが、一般的な食品店舗全体を再現するためにはデ 一タが不足しており、多段以外の平台やガラス扉付きのリーチイン型 $\mathrm{SC}$ の冷却負荷特性の把握が必要である。さらに空調負荷に与える影 響を評価するには、SC 冷却負荷の潜熱・顕熱負荷特性について明ら かにする必要がある。

$\mathrm{SC}$ 冷却負荷特性を得た後の予測計算では、既往文献 5)7)のいずれの 場合も店内温湿度については数值を予め与え計算を行っている。店内 温湿度は SC 冷却負荷の重要なパラメータであるが、実際には SC か らの漏洩冷熱と空調負荷の釣り合いによって決まるため、空調を含め た店舗全体のエネルギー計算を行う場合には一定值として与えるこ とはできない。さらに、SCからの漏洩冷熱によって生じる吸熱負荷 を店内完全混合状態として計算すると、 $\mathrm{SC}$ の侵入空気のエンタルピ が過大に低下してしまうため、鉛直方向の温湿度分布を考慮し、店内 温湿度を与える必要がある。

以上の背景を鑑夕て、本研究では SC 種別毎の漏洩冷熱や外気流入 により変化する店内温湿度を考慮して前提条件を与える方法を考案 し、それらと実験室実験より得られた各種 SC 特性式から冷却負荷を

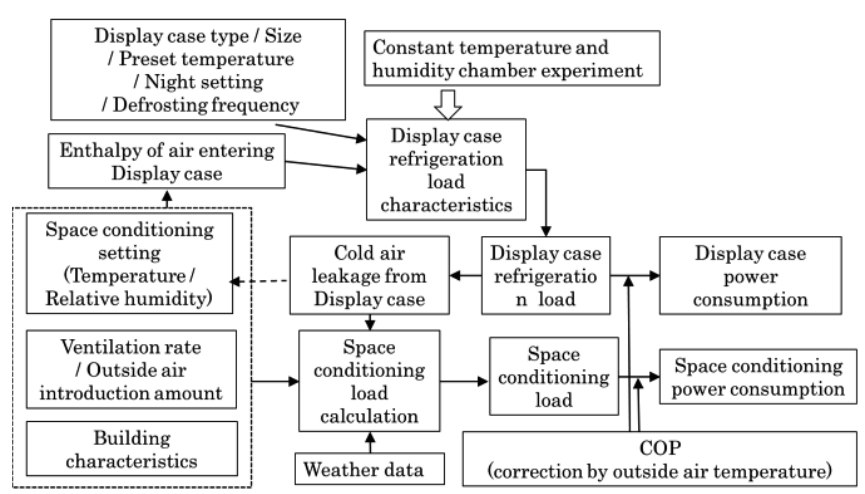

Fig.1 Energy consumption calculation method
計算する手法を確立する。さらに、空調負荷計算と組み合わせること で、店舗の空調・換気・SC のエネルギー消費量を計算し、各種省エ ネ施策が店舗のエネルギー消費に与える影響を明らかにする。

本論文（その 1) では、食品小売店舗の空調・SC エネルギー計算の 実施において重要な要素となる $\mathrm{SC}$ 冷却負荷特性について述べる。食 品小売店舗において一般的に用いられる代表的な SC について、恒温 恒湿実験室を用いて異なる室内温湿度条件における冷却負荷、消費電 力等の基本特性の違いを整理する。また冷蔵多段 SCについては、今 後のエネルギー計算に必要となる周辺温度分布や設定温度を変更し た場合の特性を整理した。第 2 報以降では、SC 冷却負荷を用いた冷 凍機消費電力計算手法、SC からの漏洩冷熱を考慮した空調負荷・空 調消費電力計算手法、食品小売店舗の省エネルギー施策とその効果に ついて報告していく予定である。本研究で想定している空調・SC 消 費エネルギー計算方法を図 1 に示す。

\section{2. 実験概要}

\section{1 対象 SC}

店舗に設置される SC には様々な仕様があるが、代表的な形状は、 壁際に設置する「多段 SC」、店舗の通路中に設置する「セミ多段 SC」 および桶型の「冷凍平台 $\mathrm{SC}$ 、ガラス扉が設置された「リーチインケ 一ス」の 4 種類、温度帯は冷蔵および冷凍の 2 種類である。本論文で は、冷蔵温度帯は多段 $(\mathrm{MD}(\mathrm{RE})) \cdot セ ミ$ 多段 $(\mathrm{SMD}(\mathrm{RE}))$ 、冷凍温度帯 は多段(MD(FR))・平台(TUB(FR))・リーチインケース $(\mathrm{RI}(\mathrm{FR}))$ の実験結 果について報告する。これら実験対象 SC の仕様概要を表 1 に、これ らと組み合わせる冷凍機の仕様を表 2 に示す。

\section{Table1 Performance of the display cases refrigeration systems}

\begin{tabular}{c|c|c|c|c|c}
\hline TYPE ${ }^{*} 1$ & $\mathrm{MD}(\mathrm{RE})$ & $\mathrm{SMD}(\mathrm{RE})$ & $\mathrm{MD}(\mathrm{FR})$ & $\mathrm{TUB}(\mathrm{FR})$ & $\mathrm{RI}(\mathrm{FR})$ \\
\hline $\begin{array}{c}\text { Operating } \\
\text { Temperature } \\
\left({ }^{\circ} \mathrm{C}\right)\end{array}$ & $-2 \sim 2$ & $-2 \sim 2$ & $-20 \sim-18$ & $-20 \sim-18$ & $-20 \sim-18$ \\
\hline $\begin{array}{c}\text { Effective } \\
\text { Unobstructed } \\
\text { Capacity(L) }\end{array}$ & 1940 & 1477 & 1507 & 1180 & 1077 \\
\hline $\begin{array}{c}\text { Outside } \\
\text { Dimension } \\
(\mathrm{mm})\end{array}$ & $\begin{array}{c}\mathrm{W} 2440 \\
\mathrm{H} 1890 \\
\mathrm{D} 1100\end{array}$ & $\begin{array}{c}\mathrm{W} 2440 \\
\mathrm{H} 1700 \\
\mathrm{D} 1100\end{array}$ & $\begin{array}{c}\mathrm{W} 2440 \\
\mathrm{H} 1880 \\
\mathrm{D} 1100\end{array}$ & $\begin{array}{c}\mathrm{W} 2440 \\
\mathrm{H} 810\end{array}$ & $\begin{array}{c}\mathrm{W} 1410 \\
\mathrm{H} 1905 \\
\mathrm{D} 760\end{array}$ \\
\hline $\begin{array}{c}\text { Required } \\
\text { Refrigerating } \\
\text { Capacity(kW) }\end{array}$ & 2.22 & 3.04 & 3.75 & $1.84 / 1.47$ & $0.6 / 0.5$ \\
\hline $\begin{array}{c}\text { Evaporating } \\
\text { Temperature } \\
\left({ }^{\circ} \mathrm{C}\right)\end{array}$ & -10 & -10 & -40 & -40 & -40 \\
\hline $\begin{array}{c}\text { Defrosting } \\
\text { Method }\end{array}$ & Off cycle & Off cycle & Heater & Heater & Heater \\
\hline
\end{tabular}

$※ 1 \quad \mathrm{MD}(\mathrm{RE})$ : an open refrigerated multi-deck display case $\mathrm{SMD}(\mathrm{RE})$ : an open refrigerated semi multi-deck display case $\mathrm{MD}(\mathrm{FR})$ : a frozen multi-deck display case

TUB(FR): a frozen tub display case

RI(FR): a frozen glass door reach-in display case

Table2 Performance of refrigerator

(Outdoor Environment : Temperature: $32^{\circ} \mathrm{C}$ Relative Humidity:40\%)

\begin{tabular}{c|c|c}
\hline & Refrigerator $(3 \mathrm{HP})$ & Refrigerator $(8 \mathrm{HP})$ \\
\hline Working refrigerant & R410a & R410a \\
\hline Evaporating Temperature $\left({ }^{\circ} \mathrm{C}\right)$ & -10 & -40 \\
\hline Freezing capacity $(\mathrm{kW})$ & 7.77 & 6.70 \\
\hline Power consumption $(\mathrm{kW})$ & 3.5 & 6.5 \\
\hline
\end{tabular}




\section{2 実験システム}

外気環境条件と店内環境条件を模擬した 2 部屋の恒温恒湿実験室 を用い、それぞれに冷凍機と SC を設置し実験を行った。

本論文に関する測定項目と実施方法を表 3 に、計測機器を表 4 に 示す。省エネルギーの検討を行うにあたり食品温度維持は重要となる ため、模擬食品を SC 内に設置し評価した。模擬食品には JIS 8 試験に 用いるテストパッケージ（標準型：W200×D100×H50mm）を用い、冷 蔵多段・冷凍多段では $576 \mathrm{~kg}$ 、冷蔵セミ多段では $528 \mathrm{~kg}$ を各段に陳列 した。その表面 (上面・前面)、中央（薄型のテストパッケージ 2 枚 で挟む）の温度を計測した。図 3 に多段ケース中央断面の計測点を示 す。冷凍平台ではペットボトルの水 $158 \mathrm{~kg}$ とテストパッケージ $41 \mathrm{~kg}$ を負荷とし、冷凍リーチインではペットボトルの氷 $72 \mathrm{~kg}$ とテストパ ッケージ $137 \mathrm{~kg}$ を負荷とした。テストパッケージ表面にセンサを設置 した。各 SC の冷却負荷を評価するためにエアカーテンの温湿度、風 速、冷媒流量、冷媒圧力、冷媒温度を計測した。それぞれの計測点を 図 4 に示す。

\section{4 実験方法}

標準的なデフロスト（以下 DF）間隔（冷蔵：6 時間毎、冷凍 : 4 時 間毎) にて稼働させ評価時間は最後の DF 開始後 1 時間を終了時刻と 決め、冷蔵 : 6 時間、冷凍 4 時間（DF を含む）とした。消費電力と泠 却負荷は負荷が安定する評価時間中の 5 時間 (冷蔵)、2 時間 30 分

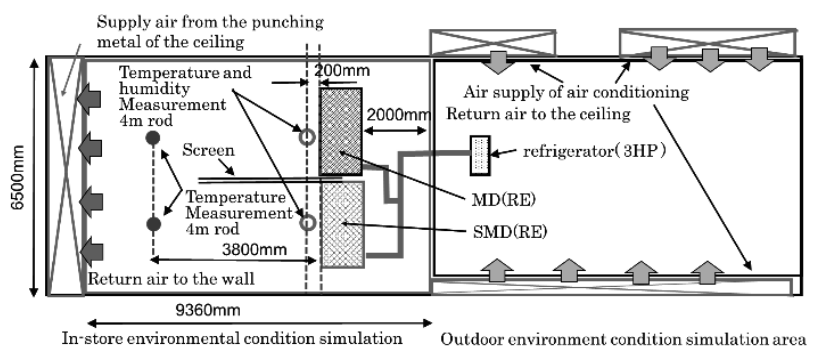

(a) Experimental apparatus for refrigerated display case

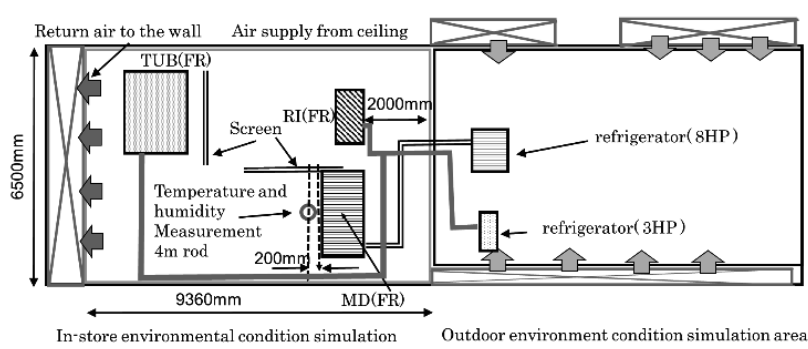

(b) Experimental apparatus for frozen display case

Fig.2 Layout of experimental equipment

（冷凍）の平均值とした。模擬食品温度は最も温度が低くなる DF 直 前の 1 時間平均值、ドレインは DF 時にまとまって排出されるため、 ドレイン量は評価時間中の積算值を評価時間で除した平均值を用い た。実験は様々な条件について条件変更に要する時間をインターバル として連続的に行うためケース内の初期温度や模擬食品温度の初期 温度は成り行き状態となっている。実験スケジュールを図 5 に示す。

\section{(1) 室内温湿度変化実験}

店舗内の温熱環境の違いが SC 冷却負荷に与える基本特性を把握す るため、店舗内の温湿度 $25^{\circ} \mathrm{C} 60 \%$ を標準状態として想定される範囲
内で温湿度条件を変化させる実験を行った。実験の温湿度条件は恒温 恒湿実験室の天井給気空気の条件である。実験室には鉛直温度分布が 生ずるため、実験室の温湿度条件とは正確には異なるが、以下では天 井給気温湿度を室内温湿度という。リーチインケースについては 2 枚 扉のうち 1 枚を 10 分に 1 回 15 秒かけて自動開閉させた。実験条件

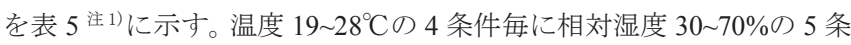
件を組み合わせ、 $5 つ$ SC に対して 20 条件の実験を行った。

\begin{tabular}{|c|c|}
\hline Items & Measuring location and method \\
\hline $\begin{array}{c}\text { Power } \\
\text { consumption }\end{array}$ & $\begin{array}{c}\text { Each device (refrigerator, case blower fan, } \\
\text { Case lighting, heater) }\end{array}$ \\
\hline $\begin{array}{l}\text { Environmental } \\
\text { measurement }\end{array}$ & $\begin{array}{c}\text { Measurement } 4 \mathrm{~m} \text { rod }{ }^{\dagger 1} \\
\text { ( } 8 \text { points in temperature }+6 \text { points in } \\
\text { temperature and humidity) }\end{array}$ \\
\hline $\begin{array}{l}\text { Temperature and } \\
\text { humidity }\end{array}$ & \multirow{2}{*}{$\begin{array}{l}\text { Air curtain air supply and inlet ( } 2 \text { to } 4 \text { points for } \\
\text { each display case air supply and inlet) }\end{array}$} \\
\hline Wind speed & \\
\hline $\begin{array}{l}\text { Refrigerant flow } \\
\text { rate }\end{array}$ & Refrigerant piping for each display case \\
\hline Food temperature & $\begin{array}{c}\text { Food surface inside display case } \\
\text { (Top, Front, Center (clamping)) } \\
\text { MD(RE):72points、MD(FR):35points } \\
\text { SMD:37points, TUB:20points, RI:24points、 }\end{array}$ \\
\hline $\begin{array}{l}\text { Weight of drain } \\
\text { water }\end{array}$ & $\begin{array}{c}\text { Continuous measurement of drain water of each } \\
\text { display case }\end{array}$ \\
\hline
\end{tabular}

$\dagger 1$ Details of the measuring rod

Temperature: FL+0.1m, 0.3m, 0.6m, $1.1 \mathrm{~m}, 1.7 \mathrm{~m}, 2.0 \mathrm{~m}, 3,0 \mathrm{~m}, 3.9 \mathrm{~m}$

Temperature and humidity: FL+0.1m, $0.3 \mathrm{~m}, 0.6 \mathrm{~m}, 1.1 \mathrm{~m}, 1.7 \mathrm{~m}, 2.0 \mathrm{~m}$

Table4 Measurement items and Methods

\begin{tabular}{c|c|c}
\hline Measurement item & Measuring equipment & Remarks \\
\hline Power Consumption & Digital power meter & YOKOGAWA \\
\hline Temperature & $\begin{array}{c}\text { T-type thermocouple } \\
\Phi 0.32 \mathrm{~mm}\end{array}$ & \\
\hline Refrigerant flow rate & Coriolis mass flow meter & $\begin{array}{c}\text { Oval, } \\
\text { Keyence }\end{array}$ \\
\hline Micro anemometer & $\begin{array}{r}\text { SSYSTEM 6244 } \\
\text { (Model 1570) }\end{array}$ & Kanomax \\
\hline $\begin{array}{c}\text { Temperature and } \\
\text { humidity }\end{array}$ & $\begin{array}{c}\text { Temperature and humidity } \\
\text { recorder RTR-503 }\end{array}$ & T\&D \\
\cline { 2 - 3 } $\begin{array}{c}\text { Simulated food } \\
\text { temperature }\end{array}$ & $\begin{array}{c}\text { K-type thermocouple } \\
\Phi 0.2 m m\end{array}$ & Vaisala \\
\hline $\begin{array}{c}\text { Weight of drain water } \\
\text { Electronic scales } \\
\text { HW-60KVWP }\end{array}$ & AND \\
\hline
\end{tabular}

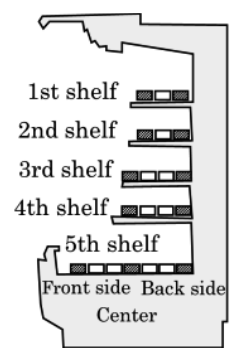

(a) Multi-deck display case

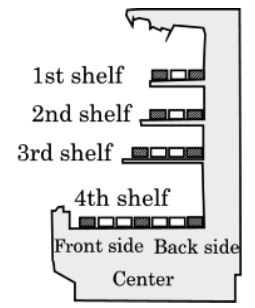

(b) Semi multi-deck display case

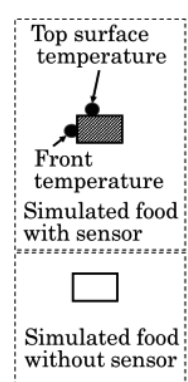

(c) Measurement point
Fig.3 Installation position of simulated food (Central cross section) and Measurement point 


\section{(2) SC 庫内設定温度変更実験}

店内環境を模擬する実験室は、天井から設定温湿度の給気を行い、 側壁面から排気するシステムとなっている。排気は SC に対面する壁 面に設置したパンチングメタルの排気口から行うが、店舗における冷 気だまりを模擬するために、高さ $1700 \mathrm{~mm}$ までの吸い込みをプラス チック段ボールにて塞いだ。冷蔵実験では、3 馬力の冷凍機 1 台に冷 蔵多段、冷蔵セミ多段を組み合わせた構成とした。機器レイアウトは、 冷凍機に対して SC2 台を並列に接続した。また、冷凍実験では 8 馬 力の冷凍機 1 台と冷凍多段 1 台を、 3 馬力の冷凍機 1 台に冷凍平台と 冷凍リーチインを並列に組み合わせたシステムとした。各 SC には、 それぞれに機械式温度自動膨張弁を設置している。冷蔵・冷凍 SC は 転倒防止のために $200 \mathrm{~mm}$ の高さの $\mathrm{H}$ 鋼に固定したため、冷気の SC 下へ入り込みを無くすように床と SC の空隙はプラスチック段ボール を用いて塞いだ。 SC 周りの室内温湿度計測のために測定ポールを設 置した。機器レイアウトと測定ポール設置位置を図 2 に示す。

\section{3 測定内容}

$\mathrm{SC}$ には温度設定器があり設定温度を容易に変更可能である。実在 店舗の SC は商品種類に合わせて様々な庫内温度に設定され、時に はデマンド抑制や省エネ運用のために、食品安全に許容される範囲 で温度を変更する場合がある。本研究では汎用的なエネルギー予測 式作成を目指しており、また、運用変更による省エネ量を定量化す

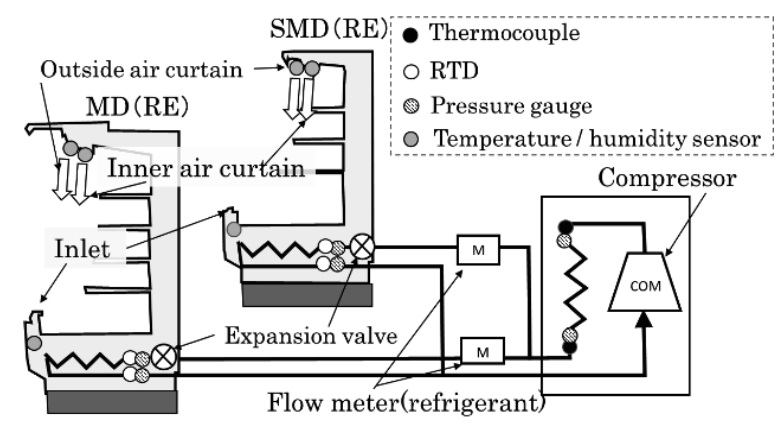

(a) Experimental system for refrigeration
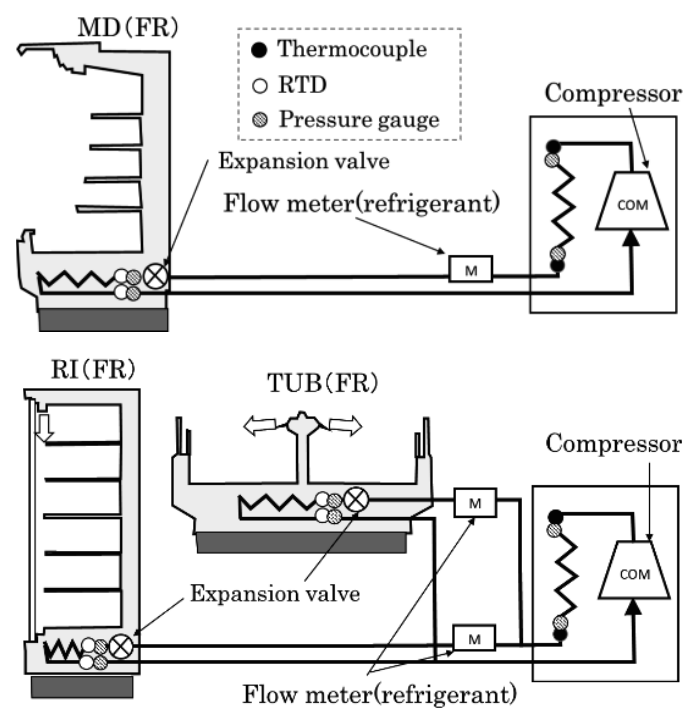

(b) Experimental system for freezing

Fig.4 Measurement points of experimental equipment

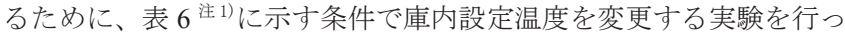
た。 $1 、 3 、 5^{\circ} \mathrm{C}$ の SC 設定温度に対して温度 3 条件毎に相対湿度 3 条件 を組み合わせ 9 条件の実験を行った。冷凍ケースでは温度変更は実 施されにくいため冷蔵のみを対象とした。

\section{（3）冷却負荷の評価方法}

冷蔵多段・冷蔵セミ多段は冷凍機能力に対して冷却負荷が小さく、 冷凍機の発停が頻繁になりフロン冷媒流量測定值に誤差を生じた。そ のため式(1)に示すようにエアカーテンの風量と吹出・吸込の温度差 から顕熱負荷を求め、ドレイン量から潜熱を計算し、それらの和を冷 却負荷（全熱）とした。熱交換器で凝縮する水分は SC の設定温度に よっては着霜しデフロスト時までドレインが排水されない場合もあ る。潜熱量はデフロスト期間を含む評価時間中の総ドレイン量の平均 值を用いて計算した。

冷凍多段、冷凍平台、冷凍リーチインについては式(2)に示すように フロン流量と SC 内部の蒸発器前後の冷媒エンタルピ差から求めた。 潜熱負荷は式(1)と同様に排出されるドレイン量を用いて計算した。

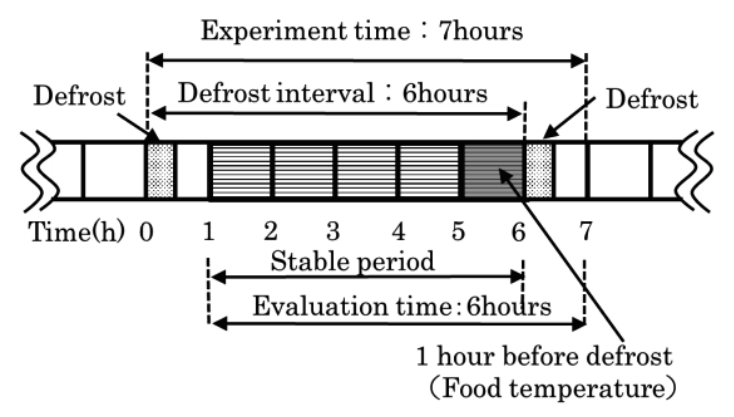

(a) Experiment of refrigerated display case

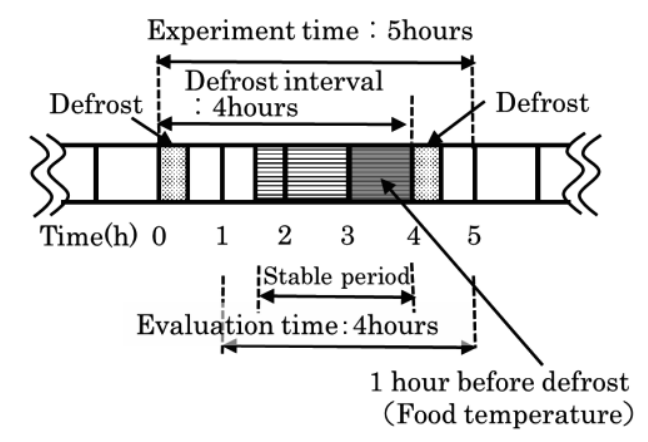

(b) Experiment of frozen display case

Fig.5 Experiment schedule

Table5 Experiment case where ambient temperature and humidity are changed

\begin{tabular}{c|c}
\hline Items & Conditions \\
\hline Outdoor \\
environment & Temperature: $32^{\circ} \mathrm{C}$ \\
Relative humidity: $40 \%$ \\
\hline $\begin{array}{c}\text { Display case } \\
\text { setting condition }\end{array}$ & $\begin{array}{c}\text { Refrigerated: preset temperature } 1^{\circ} \mathrm{C} \\
\text { Open and close the solenoid valve according to } \\
\text { the evaporator outlet temperature }\end{array}$ \\
\hline Ambient & Air supply temperature from the ceiling \\
temperature & $: 19,22,25,28^{\circ} \mathrm{C}$ \\
\hline $\begin{array}{c}\text { Ambient relative } \\
\text { humidity }\end{array}$ & $\begin{array}{c}\text { Air supply relative humidity from the ceiling } \\
: 30,40,50,60,70 \%\end{array}$ \\
\hline Number of & Refrigerated: 20 cases \\
experiments & Frozen: 20 cases \\
\hline
\end{tabular}




$$
\begin{aligned}
& T C L_{A}=\left(t_{\text {sa- }} t_{\text {re }}\right) \cdot q_{m_{-} \text {air }} \cdot c_{p}+d_{\text {rate }} \cdot r_{\text {water }} \\
& T C L_{R}=\left(h_{\text {out }}-h_{\text {in }}\right) \cdot q_{m_{-} r e f}
\end{aligned}
$$

\begin{tabular}{|c|c|c|}
\hline$T C L_{A}$ & $\mathrm{~kW}$ & $\begin{array}{l}\text { Total heat cooling load } \\
\text { Calculated from air curtain }\end{array}$ \\
\hline$T C L_{R}$ & $\mathrm{~kW}$ & $\begin{array}{l}\text { Total heat cooling load } \\
\text { Calculated from refrigerant }\end{array}$ \\
\hline$t_{s a}$ & ${ }^{\circ} \mathrm{C}$ & Air curtain supply temperature \\
\hline$t_{r e}$ & ${ }^{\circ} \mathrm{C}$ & Air curtain return temperature \\
\hline$q_{m \_a i r}$ & $\mathrm{~kg} / \mathrm{s}$ & Mass flow rate of air curtain \\
\hline$c_{p}$ & $\mathrm{~kJ} / \mathrm{kg} \cdot{ }^{\circ} \mathrm{C}$ & Constant pressure specific heat of air \\
\hline$d_{\text {rate }}$ & $\mathrm{kg} / \mathrm{s}$ & Drain water weight \\
\hline$r_{\text {water }}$ & $\mathrm{kJ} / \mathrm{kg}$ & Heat of evaporation of water \\
\hline$h_{\text {out }}$ & $\mathrm{kJ} / \mathrm{kg}$ & $\begin{array}{l}\text { Specific enthalpy of refrigerant at the } \\
\text { outlet of the evaporator }\end{array}$ \\
\hline$h_{i n}$ & $\mathrm{~kJ} / \mathrm{kg}$ & $\begin{array}{l}\text { Specific enthalpy of refrigerant at the } \\
\text { evaporator inlet }\end{array}$ \\
\hline$q_{m \_r e f}$ & $\mathrm{~kg} / \mathrm{s}$ & Refrigerant mass flow \\
\hline
\end{tabular}

\section{SC 冷却特性}

\section{1 時系列変化の一例}

図 6 に室内条件 $19^{\circ} \mathrm{C} 30 \%$ 、図 7 に室内条件 $25^{\circ} \mathrm{C} 60 \%$ の冷凍多段実 験の時系列変化を示す。図 5 に示したように、評価時間は実験後半の デフロスト開始後 1 時間を終了時刻として 4 時間としている。室内 エンタルピが低い条件 $\left(29.4 \mathrm{~kJ} / \mathrm{kg}\left(19^{\circ} \mathrm{C} 30 \%\right)\right)$ では冷凍機が断続運転 しているが、エンタルピがやや高い条件 $\left(55.5 \mathrm{~kJ} / \mathrm{kg}\left(25^{\circ} \mathrm{C} 60 \%\right)\right)$ では $\mathrm{SC}$ 負荷が増加するため冷凍機が連続運転している。平均模擬食品温

Table6 Case of experiment which changed presetting temperature of display case

\begin{tabular}{c|c}
\hline Items & Conditions \\
\hline Outdoor & Temperature: $32^{\circ} \mathrm{C}$ \\
environment & Relative humidity $40 \%$ \\
\hline Display case & Refrigerated: preset temperature \\
setting condition & $1,3,5^{\circ} \mathrm{C}$ \\
\hline Ambient & Air supply temperature from the ceiling \\
temperature & $: 19,25,28^{\circ} \mathrm{C}$ \\
\hline Ambient relative & Air supply relative humidity from the ceiling \\
humidity & $: 30,60,70 \%$ \\
\hline Number of & Refrigerated: 9 cases \\
experiments &
\end{tabular}

度は室内エンタルピによらず $-10^{\circ} \mathrm{C}$ 程度となるが、冷凍機の断続運転 による温度上昇が見られる。

\section{2 冷却負荷}

図 8 から 12 に各 SC の潜熱・顕熱負荷を示す。図 8 に冷蔵多段、 図 9 に冷蔵セミ多段の特性を比較する。セミ多段が多段に比べて 3 割 程度負荷が大きくなっており、エンタルピ $50 \mathrm{~kJ} / \mathrm{kg}$ では冷蔵多段の 冷却負荷が $2.14 \mathrm{~kW}$ 、冷蔵七ミ多段の負荷が $2.73 \mathrm{~kW}$ となっている。 セミ多段は多段に比べて陳列できる容量は小さいが、SC 下部が前に せり出す形状であり、エアカーテンも斜めに吹き出すことから、冷気 漏洩が相対的に多くなることによる。SHF は冷蔵多段も冷蔵セミ多 段も同様の傾向を示し、エンタルピが $30 \mathrm{~kJ} / \mathrm{kg}$ と低い場合は 1.0 に近 く潜熱負荷が小さい一方で、エンタルピが $60 \mathrm{~kJ} / \mathrm{kg}$ と高くなると SHF は 0.6 まで低下する。

図 10 に冷凍多段の特性を示す。SC 庫内温度が低く、庫内外の温度 差が大きくなるために SHF が大きく、高エンタルピ条件でも 0.8 以 上となっている。エンタルピ $50 \mathrm{~kJ} / \mathrm{kg}$ では冷凍多段の冷却負荷は
$9.3 \mathrm{~kW}$ となった。図 11 に冷凍平台、図 12 に冷凍リーチインの特性を 示す。両ケースとも SHF が高くエンタルピによらず 1.0 となってい る。これは $\mathrm{SC}$ へ侵入空気がほとんど無いことから、空気中の水蒸 気をケース内に取り込まないためと考えられる。冷凍平台はわずかな がらエンタルピに対する冷却負荷の増加が見られる。これは微少な空 気流入や天井壁との輻射の影響と考えられる。

冷蔵多段・冷蔵セミ多段の設定温度を標準の $1^{\circ} \mathrm{C}$ から、 $3^{\circ} \mathrm{C}$ もく は $5^{\circ} \mathrm{C}$ 一変更した場合の泠却負荷を図 13 に示す。今回の実験システ ムでは、設定温度が $2^{\circ} \mathrm{C}$ 上がる毎に $15 \%$ 程度冷却負荷が減少した。 SHF は設定温度上昇によりわずかに上昇する。 SC の設定温度が上昇 すると制御用の温度センサの值によって SC に内蔵する冷媒電磁弁の 開いている時間が短くなり SC 冷却負荷も小さくなる。冷凍機には冷 却負荷が小さくなると圧縮機回転数を下げて冷凍サイクルの低圧圧 力を上げる省エネルギー制御があるため、SC 冷却負荷より冷凍機能 力が過大になってくると蒸発温度が上昇する。それにより SC 冷却潜 熱負荷が減少し SHF は上昇する。

\section{3 食品温度}

標準状態である室内温度 $25^{\circ} \mathrm{C}$ 相対湿度 $60 \%$ の場合の模擬食品温度 (テストパッケージ) の分布について、図 14 に冷蔵多段、図 15 に冷 蔵セミ多段の結果を示す。棚の奥側は棚の上下によらず低い温度を保 っているが、下段の方が SC 前面からの奥行きがあるため若干温度が 下がっている。また棚奥からも冷気吹出があるため模擬食品温度の前 面よりも上面の温度が低い。棚の前面側では多段・セミ多段ともに下

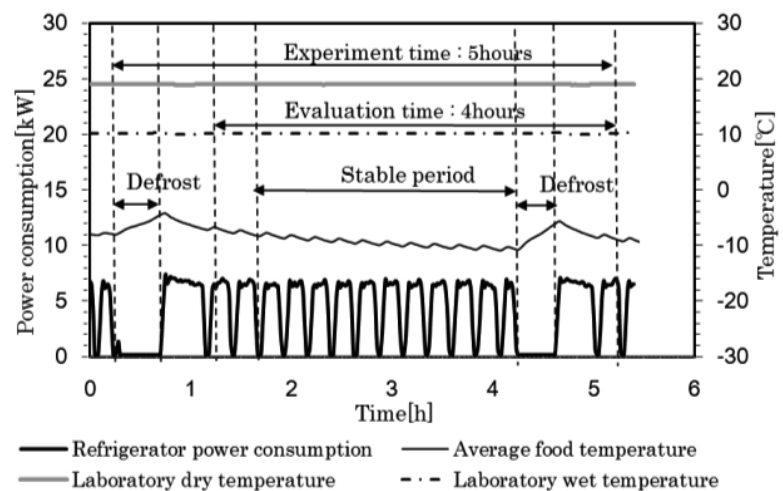

Fig.6 Time transition of $\mathrm{SC}(\mathrm{MD}(\mathrm{FR}))$ experiment data Experimental conditions (temperature: $19^{\circ} \mathrm{C}$, relative humidity: $30 \%$ )

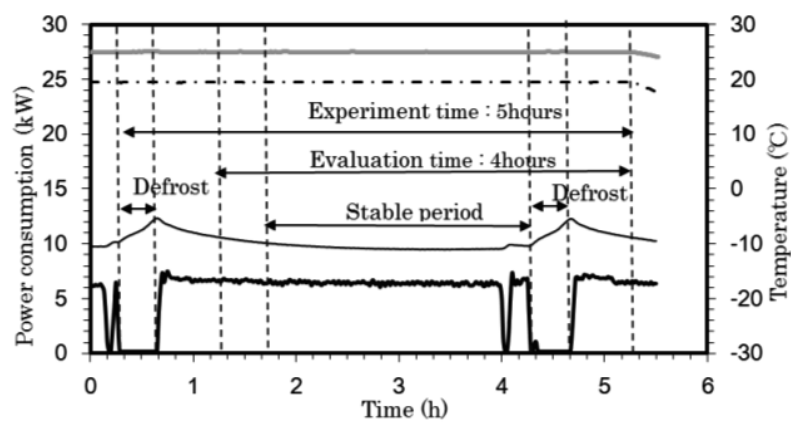

- Refrigerator power consumption - Average food temperature Laboratory dry temperature - - - Laboratory wet temperature

Fig.7 Time transition of SC(MD(FR)) experiment data Experimental conditions (temperature: $25^{\circ} \mathrm{C}$, relative humidity: $60 \%$ ) 


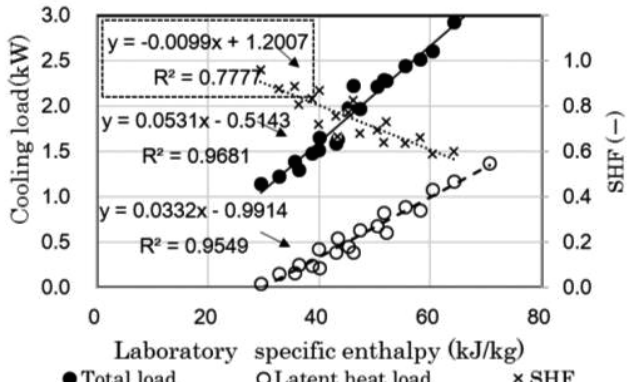

- Total load

Fig.8 Relationship between laboratory specific enthalpy and cooling load and SHF(MD(RE))

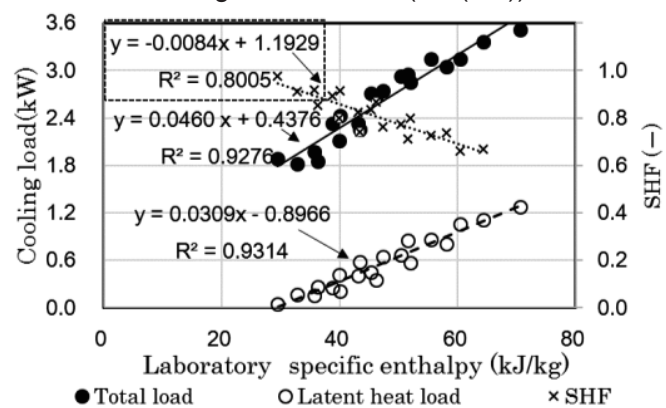

Fig.9 Relationship between laboratory specific enthalpy and cooling load and SHF(SMD(RE))

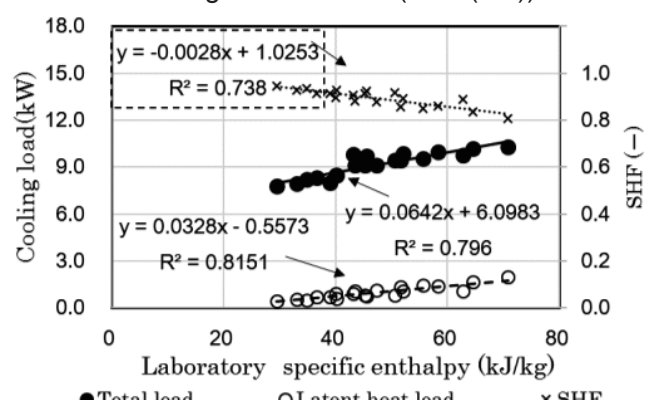

Total load

Fig.10 Relationship between laboratory specific enthalpy and cooling load and SHF(MD(FR))

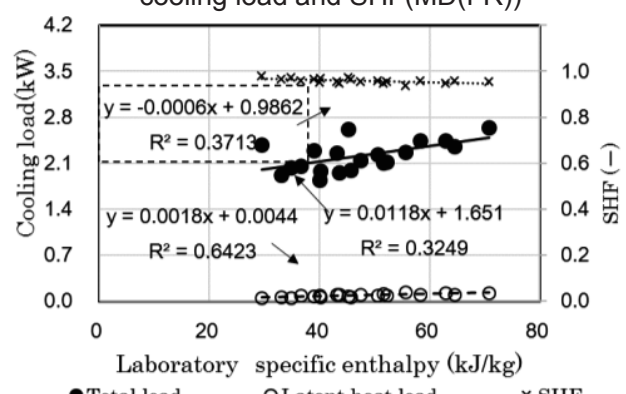

Fig.11 Relationship between laboratory specific enthalpy and cooling load and SHF(TUB(FR))

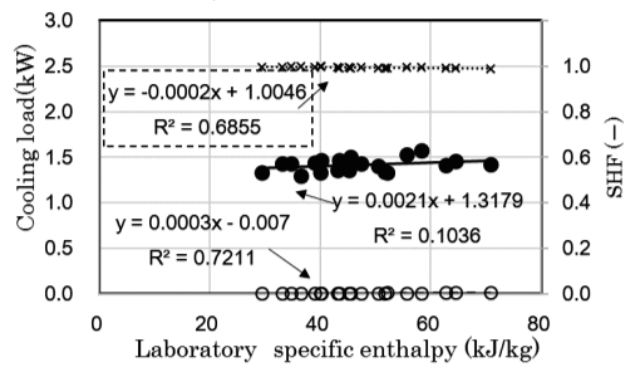

-Total load OLatent heat load $\quad \times$ SHF

Fig.12 Relationship between laboratory specific enthalpy and cooling load and SHF (RI(FR))

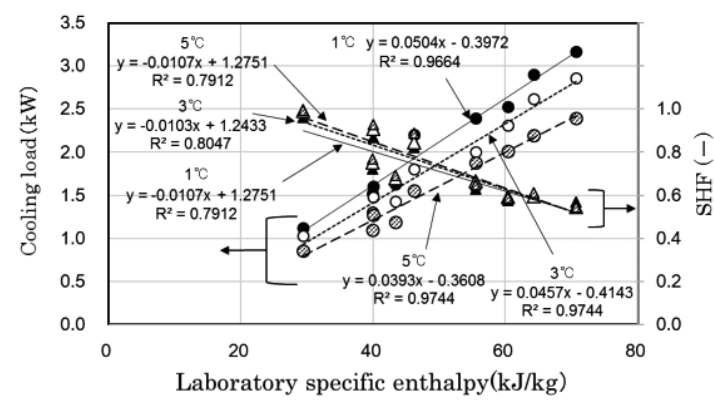

- Total load (preset:1 ${ }^{\circ} \mathrm{C}$ ) o Total load (preset: $3^{\circ} \mathrm{C}$ ) $\odot$ Total load (preset:5 ${ }^{\circ} \mathrm{C}$ $\triangle \mathrm{SHF}\left(\right.$ preset: $\left.1^{\circ} \mathrm{C}\right) \quad \Delta \mathrm{SHF}\left(\right.$ preset: $\left.3^{\circ} \mathrm{C}\right) \quad \Delta \mathrm{SHF}\left(\right.$ preset: $\left.5^{\circ} \mathrm{C}\right)$

Fig.13 Relationship between change in display case presetting temperature and cooling load and SHF (MD(RE))

段になるに従い店内空気の庫内侵入の影響を受けて温度が上昇し、そ の影響は模擬食品温度の前面側がより大きく受けている。セミ多段は その形状から店内空気流入の影響が多段に比べて大きくなり、模擬食 品温度も全体的に高くなっている。眓 8 および図 9 に示すように冷 蔵セミ多段の冷却負荷が冷蔵多段の冷却負荷よりも約 1.5 倍大きい原 因となっている。室内のエンタルピ上昇に対する模擬食品温度の変化 について、図 16 に冷蔵系、図 17 に冷凍系の結果を示す。模擬食品温 度は、多段系の場合、最下段の中央前面が庫内で最も温度が高くなる ため、そのポイントの DF 直前の 1 時間平均温度を示した。平台につ いては表面中央に設置した 2 点の平均值を、リーチインは扉開閉時に 最も空気にさらされる時間が長い、上から 4 段目の前面温度を用い、 いずれも冷蔵と同様に整理した。冷蔵の場合は、エンタルピが低い場 合でも、冷媒供給用電磁弁が頻繁に開閉することで模擬食品温度が低 くならないなど、冷凍機と冷却負荷のバランスによって模擬食品温度 が変化するため相関が低くなっている。一方、冷凍多段の場合はエン タルピとの相関が高く、高エンタルピ条件では模擬食品温度が高くな りすぎている。これは冷蔵多段の場合は、DF 直後と直前の SC エア カーテン吹き出し風速に変化が無いが、冷凍多段の場合は、DF 直後 と直前のエアカーテン風速が、室内温湿度 $19^{\circ} \mathrm{C} 60 \%$ の場合 $10 \%$ 、室 内温湿度 $28^{\circ} \mathrm{C} 60 \%$ の場合 $18 \%$ 減少することから、熱交換器の着霜に より十分な冷却ができていないことが原因として考えられる。冷凍 $\mathrm{SC}$ で推奨される除霜間隔の 4 時間は通常の使用温度範囲における值 であるため、室内温度 $28^{\circ} \mathrm{C}$ では除霜間隔が長すぎる結果となった。 冷凍平台と冷凍リーチインはエンタルピ上昇の影響がほとんどない。

冷蔵多段・冷蔵セミ多段の設定温度を標準の $1{ }^{\circ} \mathrm{C}$ か、 $3^{\circ} \mathrm{C}$ もく は $5^{\circ} \mathrm{C}$ 一変更した場合の模擬食品温度を図 18 に示す。模擬食品温度 は設定温度変更に伴い上昇する。同じ設定温度でも室内エンタルピが 低くなることで模擬食品温度もわずかに下がる傾向がある。エンタル ピが $55 \mathrm{~kJ} / \mathrm{kg}$ （例えば温度約 $25^{\circ} \mathrm{C} 、$ 湿度 $60 \%$ ）における設定温度 $1^{\circ} \mathrm{C}$ の模擬食品温度 $6.5^{\circ} \mathrm{C}$ を許容值とすれば、エンタルピが $27 \mathrm{~kJ} / \mathrm{kg}$ （例え ば温度約 $17^{\circ} \mathrm{C}$ 、湿度 $32 \%$ ）における設定温度 $3^{\circ} \mathrm{C}$ の模擬食品温度と同 等となるため、室内エンタルピによっては、設定温度を緩和できる可 能性がある。但し、これらの特性はシステム固有であり、SC 管理シ ステム等による情報取得・分析することで実現できる可能性がある。

\section{4 冷凍機消費電力}

実験室の室内温湿度変化に対する冷凍機電力の変化を整理した。冷 
蔵多段、冷蔵セミ多段の実験結果を図 19 に、冷凍多段の実験結果を 図 20 に示す注 2)。多段式 SC では、室内温度が上昇・下降すると SC の顕熱負荷が増加・減少する。また室内温度が同じでも湿度が上昇・ 下降すると潜熱負荷が増加・減少する。それに伴い冷凍機電力が増加・ 減少する。例えば $25^{\circ} \mathrm{C} 60 \%$ を基準とすれば、冷蔵多段・冷蔵セミ多段 の冷凍機消費電力は $19^{\circ} \mathrm{C} 60 \%$ では $29 \% 、 25^{\circ} \mathrm{C} 40 \%$ では $19 \%$ 減少し、冷 凍多段の冷凍機消費電力は $19^{\circ} \mathrm{C} 60 \%$ では $6 \%$ 、 $25^{\circ} \mathrm{C} 40 \%$ では 7\%減少 した。冷凍多段に関して、28 $\mathrm{C}$ の実験では冷凍機の能力が不足してお り熱交換器の着霜が多いため湿度が上昇しても消費電力が増加して いないが、 $25^{\circ} \mathrm{C}$ 以下では冷蔵多段と同様の傾向が見られた。図 21 に 冷凍平台と冷凍リーチインを接続した冷凍機の結果を示す注 ${ }^{3)}$ 。温度

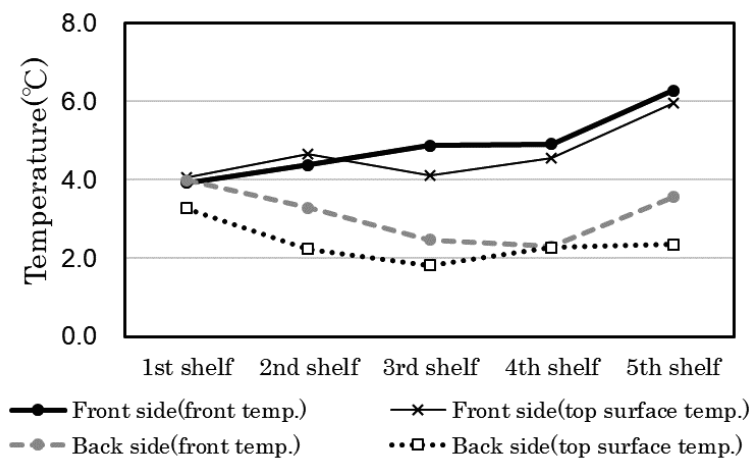

Fig.14 Food temperature distribution (MD (RE)) Experimental conditions

(temperature: $25^{\circ} \mathrm{C}$, relative humidity: $60 \%$ )

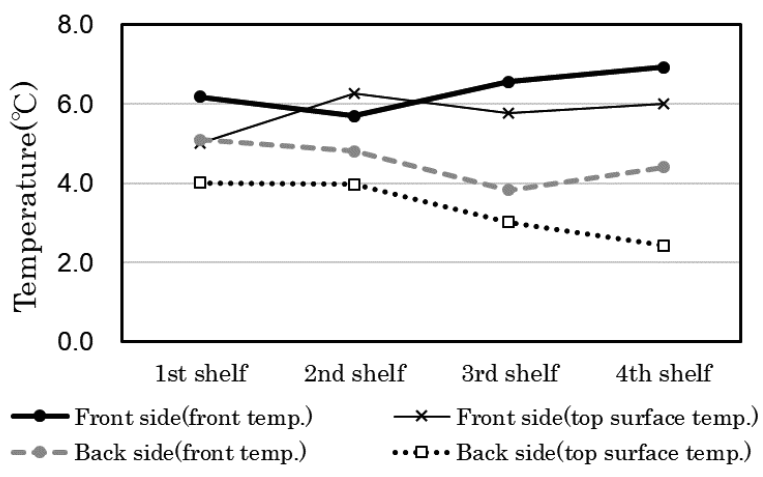

Fig.15 Food temperature distribution (SMD (RE)) Experimental conditions

(temperature: $25^{\circ} \mathrm{C}$, relative humidity: $60 \%$ )

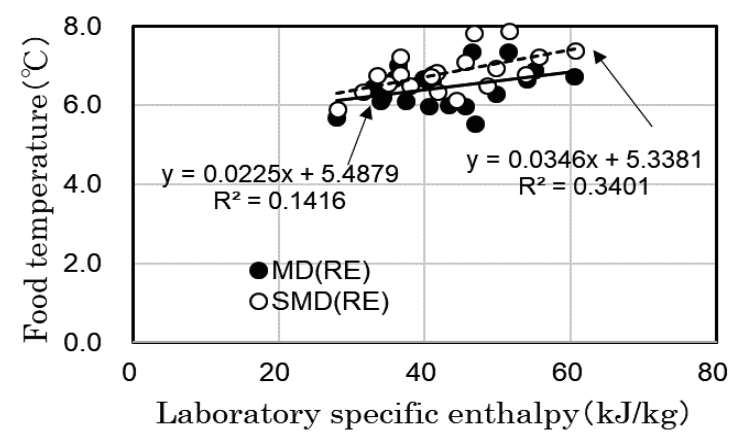

Fig.16 Relationship between laboratory specific enthalpy and food temperature (MD(RE), SMD(RE))
上昇によって消費電力は増加するが相対湿度が増加しても消費電力 は増加しない。

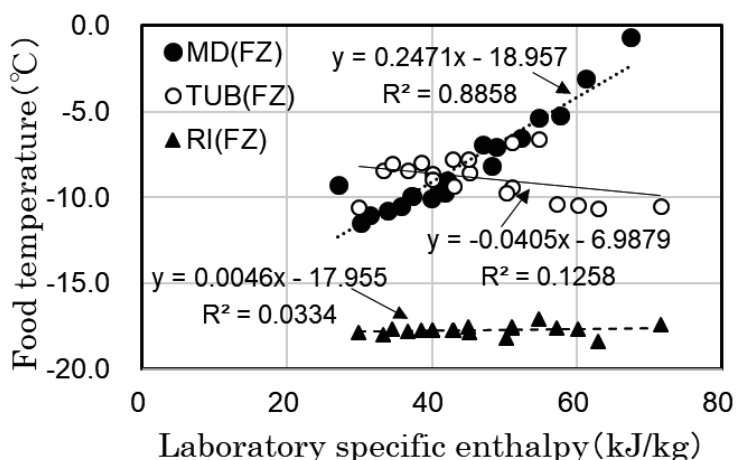

Fig.17 Relationship between laboratory specific enthalpy and food temperature (MD(FR), TUB(FR), RI(FR))

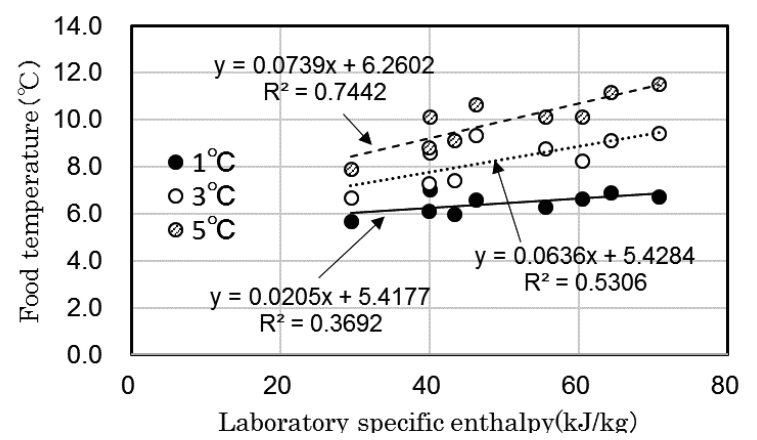

Fig.18 Relationship between change in display case presetting temperature and food temperature $(\mathrm{MD}(\mathrm{RE}))$

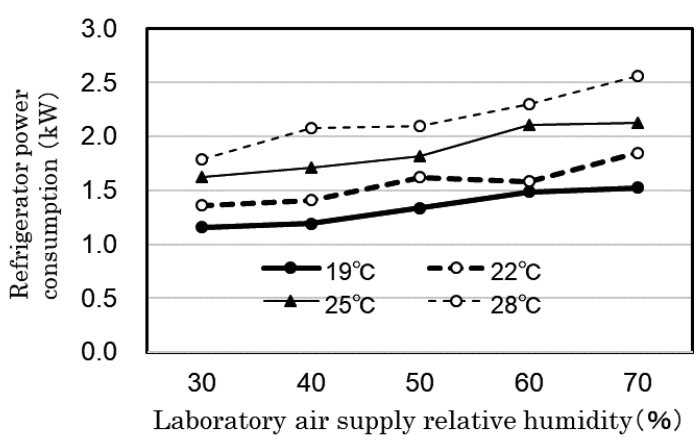

Fig.19 Relationship between temperature and humidity conditions and refrigerator power(MD(RE),SMD(RE))

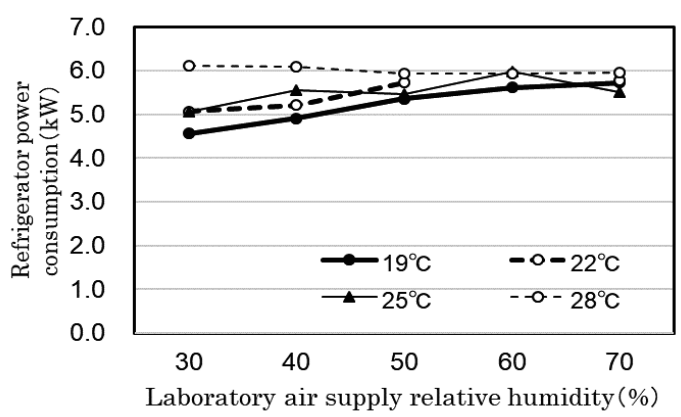

Fig.20 Relationship between temperature and humidity conditions and refrigerator power(MD(FR)) 
3 台の冷凍機の消費電力と室内のエンタルピとの関係を図 22 に示 す。多段型では冷蔵・冷凍ともにエンタルピ上昇に伴い消費電力が増 加しており、エンタルピ $30 \mathrm{~kJ} / \mathrm{kg}$ から $50 \mathrm{~kJ} / \mathrm{kg}$ 変化時の変化量は冷凍 $1.16 \mathrm{~kW}$ 、冷蔵 $0.93 \mathrm{~kW}$ と冷凍が大きい。増加率は冷凍が 1.24 倍、冷蔵 が 1.8 倍となり冷蔵の変化率が大きい。冷凍平台と冷凍リーチインは $\mathrm{SC}$ への空気流入が小さく、冷凍機消費電力はエンタルピ変化に対し て明確な変化は見られない。

冷蔵多段・冷蔵七ミ多段の設定温度を標準の $1^{\circ} \mathrm{C}$ から、 $3^{\circ} \mathrm{C}$ もく は $5^{\circ} \mathrm{C}$ 一変更した場合の冷凍機消費電力を図 23 に示寸。冷凍機消費 電力は冷却負荷の減少に従い設定温度が $2^{\circ} \mathrm{C}$ 上昇する毎に $12 \sim 14 \%$ 減少する。

\section{SC システムの消費電力}

各 SC の冷凍機電力を含めた消費電力量の内訳を整理した。デフロ ストを含む評価時間帯の平均電力量について、低エンタルピ $\left(19^{\circ} \mathrm{C}\right.$ $30 \%)$ 実験值を図 24 に、通常エンタルピ $\left(25^{\circ} \mathrm{C} 60 \%\right)$ 実験值を図 25

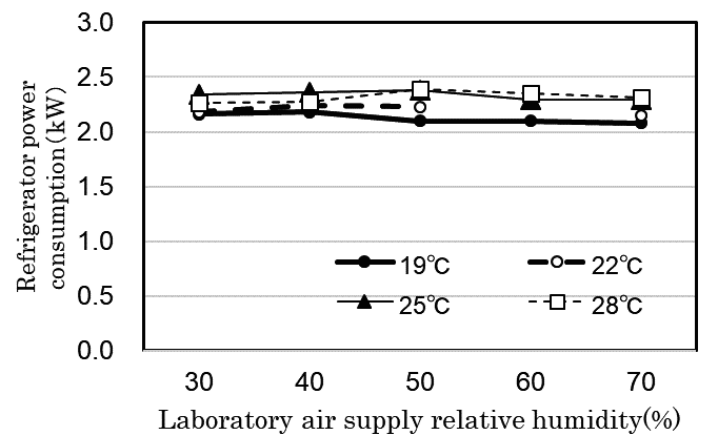

Fig.21 Relationship between temperature and humidity conditions and refrigerator power(TUB(FR), RI(FR))

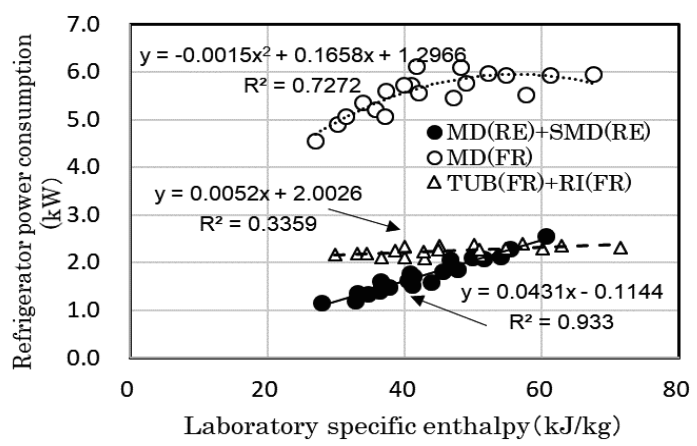

Fig.22 Relationship between laboratory specific enthalpy and refrigerator power

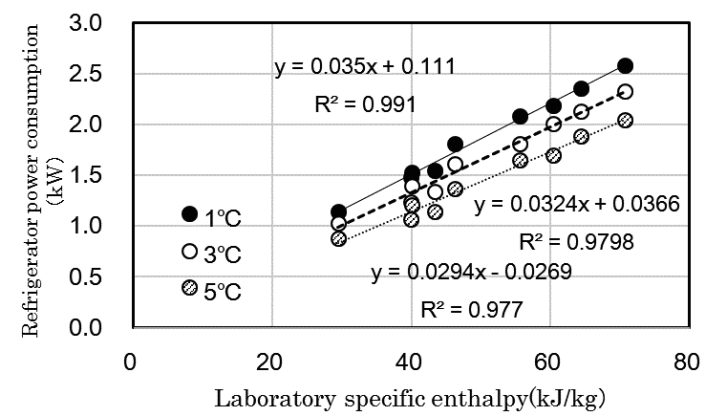

Fig.23 Relationship between change of display case presetting temperature and power consumption of refrigerator

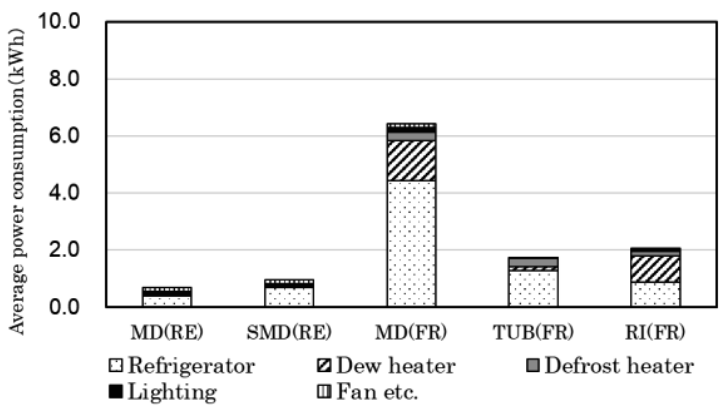

Fig.24 Power consumption of display case and refrigerator Experimental conditions

(temperature: $19^{\circ} \mathrm{C}$, relative humidity: $30 \%$ )

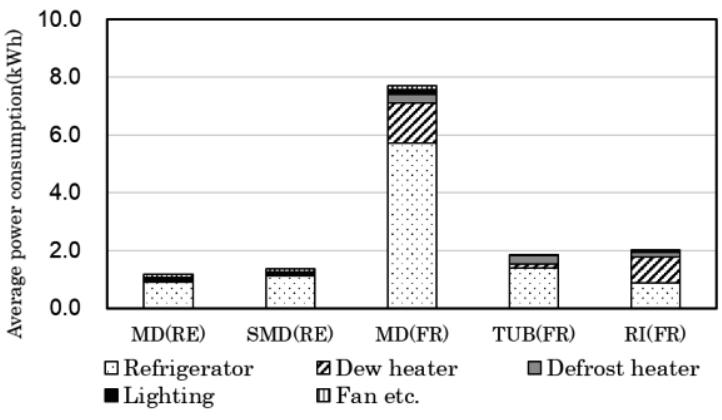

Fig.25 Power consumption of display case and refrigerator Experimental conditions

(temperature: $25^{\circ} \mathrm{C}$, relative humidity: $60 \%$ )

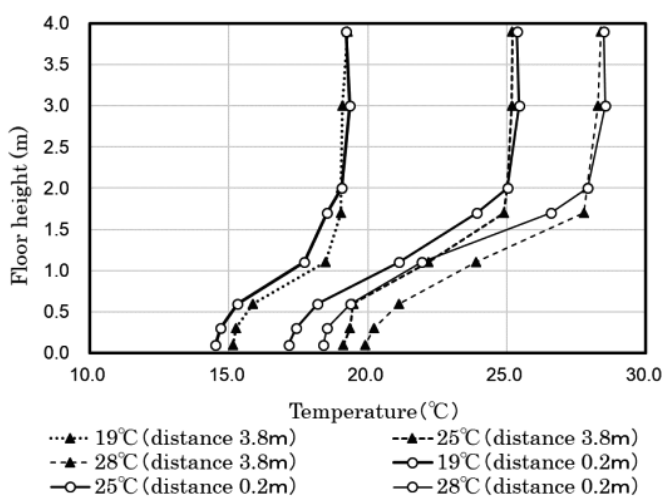

Fig.26 Vertical temperature distribution on the front of the display case (MD(RE) distance $200 \mathrm{~mm}, 3800 \mathrm{~mm}$ )

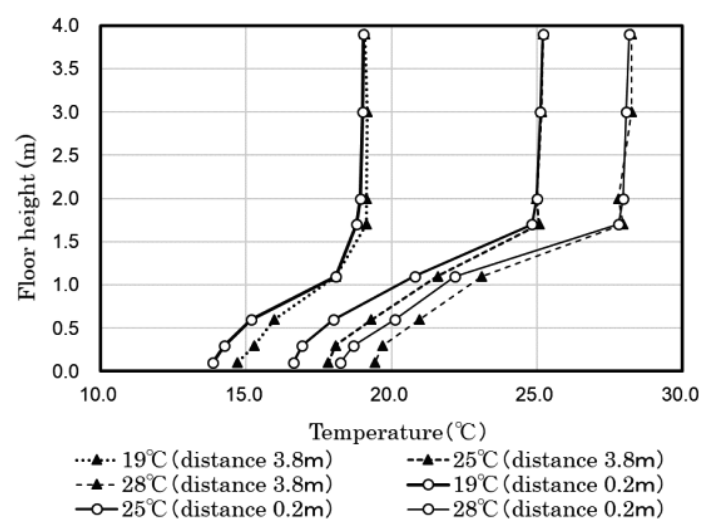

Fig.27 Vertical temperature distribution on the front of the display case $(\mathrm{SMD}(\mathrm{RE})$ distance $200 \mathrm{~mm}, 3800 \mathrm{~mm})$ 
に示す。冷凍機電力は各 SC の泠却負荷の比で按分した。各 SC の電 力負荷内訳を見ると、冷凍機の次に冷凍多段の防露ヒータの消費電力 が大きくなっている。室内の温湿度が変化すると多段 SC の冷凍機消 費電力は増減するが、防露ヒータやデフロストヒータの電力量は変化 しない。この点に関して室内エンタルピが低ければ露点が低くなり着 霜が少なくなるため、室内エンタルピに合わせて各ヒータの調整を行 うことが省エネルギーには重要と考えられる。注3)

\section{SC 周辺の温度分布}

$\mathrm{SC}$ 前の鉛直温度分布の測定結果について、冷蔵多段を図 26 に、冷 蔵セミ多段を図 27 に示す。先述のように実験室の排気口にはプラス チック段ボール板を設置しており、冷気は概ね FL 2.0m まで滞留し、 その高さから温度降下が始まっている。室内エンタルピが低い場合は 漏洩冷熱量が少ないために温度降下幅が小さく、室内エンタルピが高 い場合は漏洩冷熱量が多いために温度降下幅が大きくなる。前述した ように冷蔵セミ多段はその形状から冷却負荷が大きく漏洩冷熱量も 多いことから冷蔵多段よりも温度降下幅が大きくなる。 SC からの距 離が $0.2 \mathrm{~m}$ の場合と比較して $3.8 \mathrm{~m}$ 離れた場合には $1^{\circ} \mathrm{C}$ 程度温度上昇が 見られるが、鉛直温度分布の傾向は変わらない。実在店舗の鉛直温度 分布は店舗換気・空調条件や SC レイアウト、入口からの距離等で決 まるが、多くの場合は今回の実験結果のように SC からの冷気漏れが 床付近に滞留し鉛直温度分布を生じている。空調負荷計算や SC 負荷 計算を行う場合に温度勾配をどのように与えるかが重要となる。注4)

\section{6. まとめ}

本論文では 5 種類の SC について実験を行い、全熱・潜熱に関する エンタルピ特性式を得た。併せて食品温度、消費電力、室内温度分布 に関して考察した。

（1）冷蔵セミ多段 SC の泠却負荷は冷蔵多段 SC よりも 3 割程度大き いが、SHF 特性には大きな差がなくエンタルピが低い $30 \mathrm{~kJ} / \mathrm{kg}$ では 1.0 近く $60 \mathrm{~kJ} / \mathrm{kg}$ では 0.6 まで低下する。

（2）冷凍多段 SC の冷却負荷は、SC 設定温度が低いため SHF が高く 0.8 以上となっている。冷却負荷の変化は冷蔵温度帯に比べて小 さいが、エンタルピに対する冷却負荷の変化量は冷蔵多段と比 較して $20 \%$ 程度大きい。

（3）冷凍平台・冷凍リーチインの泠却負荷は、SC 設定温度が低いた め冷凍多段と同様に SHF は高く、店内空気の侵入量が小さいた め、高エンタルピ時でも 1.0 に近い值となった。冷却負荷の室内 エンタルピに対する変化量もごく小さい。

（4）冷蔵多段・冷蔵セミ多段の設定温度を $1^{\circ} \mathrm{C} 、 3^{\circ} \mathrm{C} 、 5^{\circ} \mathrm{C}$ と変更した 場合、今回の実験システムでは、設定温度が $2{ }^{\circ} \mathrm{C}$ 上がる毎に $15 \%$ 程度冷却負荷が減少した。SHF は設定温度上昇によりわずかに 上昇する。

(5) 棚の前面側の模擬食品温度は多段・セミ多段ともに下段になる に従い店内空気の庫内侵入の影響を受けて温度が上昇する。セ ミ多段はその形状から店内空気流入の影響が多段に比べて大き くなり、模擬食品温度も全体的に高くなっている。

（6）冷蔵多段の場合は、室内エンタルピが低くなることで模擬食品 温度もわずかに下がる傾向がある。一方、冷凍多段は高エンタル ピ条件では着霜の影響が現れ能力が低下寸ることから模擬食品
温度が設定温度よりも大幅に高くなってしまう場合がある。冷 凍平台と冷凍リーチインの模擬食材温度は室内エンタルピ上昇 の影響がほとんどない。

（7）多段型では冷蔵・冷凍ともにエンタルピ上昇に伴い消費電力が 増加しており、エンタルピ $30 \mathrm{~kJ} / \mathrm{kg}$ から $50 \mathrm{~kJ} / \mathrm{kg}$ 変化時の変化量 は冷凍 $1.16 \mathrm{~kW}$ 、冷蔵 $0.93 \mathrm{~kW}$ と冷凍が大きい。増加率は冷凍が 1.24 倍、冷蔵が 1.8 倍となり冷蔵の変化率が大きい。冷凍平台と 冷凍リーチインは SC への空気流入が小さく、冷凍機消費電力は エンタルピ変化に対して明確な変化は見られない。

(8) 冷蔵多段・冷蔵七ミ多段の設定温度を標準の $1^{\circ} \mathrm{C} 、 3^{\circ} \mathrm{C} 、 5^{\circ} \mathrm{C}$ 一変 更した場合、冷凍機消費電力は冷却負荷の減少に従い設定温度 が $2^{\circ} \mathrm{C}$ 上昇する毎に $12 \sim 14 \%$ 減少する。

（9） SC システムの消費電力の内訳では、冷凍機の次に冷凍多段の防 露ヒータの消費電力が大きくなっている。室内の温湿度が変化 すると多段 SC の冷凍機消費電力は増減するが、防露ヒータやデ フロストヒータの電力量は変化しない。室内エンタルピに合わ せて各ヒータの調整を行うことが省エネルギーには重要と考え られる。

(10) SC の漏洩冷熱は店舗内に大きな鉛直温度分布を生じる。本実験 条件では冷気は FL $2.0 \mathrm{~m}$ まで滞留し、その高さから温度低下が生 じた。室内エンタルピが低い場合は漏洩冷熱量が少ないために 温度降下幅が小さく、室内エンタルピが高い場合は漏洩泠熱量 が多いために温度降下幅が大きくなる。空調負荷と SC 負荷の相 互影響の計算を行う場合は鉛直温度分布を考慮する必要がある。

今後は店舗内の鉛直温度分布を考慮した空調負荷計算・冷却負荷計 算方法の検討を行い、それら手法を用いて省エネルギー手法の検討・ 評価を行う。なお，本論文で示した結果の一部は，空気調和・衛生工 学会大会学術講演会 ${ }^{9}$ にて既に発表した内容を含む.

\section{謝辞}

本研究を行うにあたり、当時横浜国立大学大学院生・吉田圭介氏、 同・陳文氏、中部電力・宮間利政氏をはじめ関係者の皆様には、多大 なるご協力を頂きました。ここに記して謝意を表します。

\section{参考文献}

1) Agency for Natural Resources and Energy : Annual Report on Energy in FY2015, Energy White Paper 2016, (in Japanese)

資源エネルギー庁：平成 27 年度エネルギーに関する年次報告，エネル ギー白書 2016

2) SHIRAISHI, K., et al.: Measurements of the Energy Consumption of Retail Stores. The Society of Heating, Air-Conditioning and Sanitary Engineers of Japan, pp.565-568, 2010.9, (in Japanese)

白石かおり，鳴海大典，山口容平，下田吉之，村上周三：食品小売店舗 におけるエネルギー消費実態調査, 空気調和・衛生工学会大会学術講演会 論文集 pp.565-568，2010.9

3) TANAKA, H., et al.: Study on the Planning and Designing of Desiccant Air Conditioning System for Supermarket (part.1). The Society of Heating, Air-Conditioning and Sanitary Engineers of Japan, pp.881884, 2003,9, (in Japanese)

田中英紀，吉川博樹，奥宮正哉，山口幸寛 : スーパーマーケットにおける デシカント空調の計画・設計に関する研究 (第 1 報) 夏期における足元吹 出式空調方式の効果検証, 空気調和・衛生工学会大会学術講演会論文集 pp.881-884, 2003.9

4) YUASA, K., et al.: Prediction of Energy Consumption in Convenience Store (part.2). The Society of Heating, Air-Conditioning and Sanitary 
Engineers of Japan, pp.1491-1494, 2007,9, (in Japanese)

湯淺和博, 藤井晴行, 小澤芳男, 藤原正人, 渡辺恵子 : コンビニエンスス トアのエネルギー消費の予測（第 2 報）コンビニエンスストアの熱負荷 計算, 空気調和・衛生工学会大会学術講演論文集 pp.1491-1494, 2007.9

5) David H. Walker, Ramin T. Faramarzi, Van D. Baxter :

Investigation of Energy Efficient Display Cases ORNL/TM-2004/292

6) Varela.D.A, Redo.M.A,Giannetti.N,Ohno.k, Yamaguchi.S and Saito.K:

Annual Performance Evaluation of $\mathrm{CO}_{2}$ Refrigerated Display Cabinets Relative to Geographical Location. Proceedings on the Japan Society of Refrigerating and Air conditioning Engineers Annual Conference, C214, 2018.9

7) NARUMI, D.: Impact of energy conservation measures of refrigerated fixtures on energy consumption at Grocery stores. The Society of Heating, Air-Conditioning and Sanitary Engineers of Japan, pp.29-32, 2015.9, (in Japanese)

鳴海大典 : 冷設什器の省エネルギー対策が食品小売店舗のエネルギー消 費に与える影響, 空気調和・衛生工学会大会学術講演会論文集, pp.29-32, 2015.9

8) Japanese Industrial Standard : JIS B-8631, 2011.

9) FUJITA, M., et al: Study on Energy Consumption of the Food Retail Store(Part1). Outline of Experiment and Results of Experiment of Cold Refrigerating Showcase. The Society of Heating, Air-Conditioning and Sanitary Engineers of Japan, pp.93-96, 2017.9, (in Japanese) 藤田美和子, 宮間利政, 吉田圭介, 鳴海大典 : スーパーマーケットのエネ ルギー消費に関する研究（第 1 報）ショーケースに関する実験概要と実 験結果、空気調和・衛生工学会大会学術講演会論文集 pp93-96, 2017.9
注1）実験条件の室内温湿度のエンタルピを以下に示す。

Sub Table 1 Correspondence between

temperature / relative humidity and enthalpy

\begin{tabular}{cc|cc|cc|cc}
\hline $\mathrm{A}$ & $\mathrm{B}$ & $\mathrm{A}$ & $\mathrm{B}$ & $\mathrm{A}$ & $\mathrm{B}$ & $\mathrm{A}$ & $\mathrm{B}$ \\
\hline $19 / 30$ & 29.4 & $22 / 30$ & 35.6 & $25 / 30$ & 40.0 & $28 / 30$ & 46.1 \\
\hline $19 / 40$ & 32.8 & $22 / 40$ & 38.8 & $25 / 40$ & 45.3 & $28 / 40$ & 52.1 \\
\hline $19 / 50$ & 36.3 & $22 / 50$ & 43.0 & $25 / 50$ & 50.4 & $28 / 50$ & 58.2 \\
\hline $19 / 60$ & 39.9 & $22 / 60$ & 47.3 & $25 / 60$ & 55.5 & $28 / 60$ & 64.3 \\
\hline $19 / 70$ & 43.3 & $22 / 70$ & 51.6 & $25 / 70$ & 60.4 & $28 / 70$ & 70.6 \\
\hline
\end{tabular}

A : temperature $\left({ }^{\circ} \mathrm{C}\right) /$ relative humidity $(\%)$

B : enthalpy $(\mathrm{kJ} / \mathrm{kg})$

注2）冷凍温度帯の室内 $22^{\circ} \mathrm{C} 60 \%$ の実験データは久損している。

注3）防露ヒータは、室内環境の露点温度以上にガラス温度を上昇させること で結露を防止している。露点温度に合わせヒータ入力を制御することが できれば、大きな省エネルギー量を得ることができる。ヒータ制御によ る省エネルギー検討については、次報以降にて報告する。

注4）実在店舗の冷気層の厚さを参考にして鉛直温度分布を仮定し、それらか ら計算する空調負荷と SC の漏洩冷熱量の関係を考慮した空調負荷・SC 冷却負荷の計算方法を次報以降に報告する。 


\section{STUDY ON ENERGY CONSUMPTION OF A GROCERY STORE (PART 1): REFRIGERATION LOAD ANALYSIS TO EVALUATE THE INTERACTION BETWEEN STORE SPACE CONDITIONING AND REFRIGERATED DISPLAY CASE}

Miwako FUJITA*1 and Daisuke NARUMI ${ }^{* 2}$

${ }^{* 1}$ Grad. Student, Graduate School of Environment and Information Sciences, Yokohama National University, B.Eng. /
Research Chief, Energy Applications Research and Development Center, Chubu Electric Power Co.
${ }^{* 2}$ Prof., Graduate School of Environment and Information Sciences, Yokohama National University, Dr.Eng.

From changes in Japan's final energy consumption, the overall increase rate from 1973 to 2013 was 1.2 times, but the increase in business divisions 2.4 times, so that energy saving is required.

Refrigeration equipment with a high energy consumption density is exposed to cost competition in the food store industry, so that energy-saving equipment is slow to spread. Therefore, it is important to save energy by devising operation and design.

From the advantage of easy to get products, many open display cases are installed in food stores. The open display case maintains the internal temperature with the air curtain, but from a part of the air curtain cold air in the refrigerator leaks from the display case and the surrounding air enters the display case. Leaked cold air stays in the lower part of the store, affects the air enthalpy in the store and worsen comfort. At the same time, air enthalpy entering display case affects the display case refrigeration load. For these reasons, the load of the open type display case interacts with the space conditioning load, making it difficult to consider energy saving.

In this study, we will devise a method to give the enthalpy of the intrusion air into the SC considering the amount of heat leaked from the SC. The SC refrigeration load is calculated by combining the enthalpy of the air entering the SC and various SC characteristics obtained from the experiment. Furthermore, by combining with air conditioning load calculation, store air conditioning, ventilation, and SC energy consumption are calculated, and the impact of various energy saving measures on store energy consumption is clarified.

In this report (1st report), two types of refrigerated temperature zones(multi-deck (MD (RE)) and semi-multideck (SMD (RE))) and three types of freezing temperature zones (multi-deck (MD (FR)) and flat tub (TUB (FR)) and glass door attachment (RI (FR))) were tested, and The enthalpy characteristic formula of total heat and latent heat was obtained. And we were able to confirm the following:

1. The refrigeration load of SMD (RE) is about 30\% larger than MD (RE). However, there is no difference in the SHF characteristics, and the enthalpy of the laboratory is close to 1.0 at $30 \mathrm{~kJ} / \mathrm{kg}$, and it decreases to 0.6 at the laboratory enthalpy of $60 \mathrm{~kJ} / \mathrm{kg}$.

2. $\mathrm{MD}$ (FR) SHF increased due to low SC pre-set temperature, and exceeded 0.8 . The change in refrigeration load is small compared to the refrigeration temperature range, but the amount of change in refrigeration load relative to enthalpy is about $20 \%$ larger than $\mathrm{MD}(\mathrm{RE})$.

3. The TUB (FR) / RI (FR) SHF was high due to the low pre-set temperature of the SC, and it was close to 1.0 even at high enthalpies due to the small amount of air in the store. The amount of change in enthalpy of the refrigeration load is very small.

4. The cold heat leaked from the SC causes a large vertical temperature distribution in the store. Under this experimental condition, the temperature decreased from about FL $2.0 \mathrm{~m}$. This coincides with the increase in the amount of leakage heat when the ambient temperature is high. When calculating the mutual influence of air conditioning load and SC load, it is necessary to consider such vertical temperature and humidity distribution. 